Pace University

DigitalCommons@Pace

Fall 2010

\title{
Iflas and Chapter 11: Classical Islamic Law and Modern Bankruptcy
}

Abed Awad

Pace Law School

Robert E. Michael

Pace Law School

Follow this and additional works at: https://digitalcommons.pace.edu/lawfaculty

Part of the Bankruptcy Law Commons, and the International Law Commons

\section{Recommended Citation}

Abed Awad \& Robert E. Michael, Iflas and Chapter 11: Classical Islamic Law and Modern Bankruptcy, 44 Int'I Law. 975 (2010), http://digitalcommons.pace.edu/lawfaculty/749/.

This Article is brought to you for free and open access by the School of Law at DigitalCommons@Pace. It has been accepted for inclusion in Pace Law Faculty Publications by an authorized administrator of DigitalCommons@Pace. For more information, please contact dheller2@law.pace.edu. 
THE INTERNATIONAL LAWYER A QUARTERLY PUBLICATION OF THE ABA/SECTION OF INTERNATIONAL LAW

\title{
Iflas and Chapter 11: Classical Islamic Law and Modern Bankruptcy*
}

\author{
Abed Awad and Robert E. Michael**
}

In many majority Muslim countries, classical Islamic law, Shari'a, is by law either $a$ source or the primary source of their national legislation. ${ }^{1}$ While the substantive compliance with this Shari'a mandate by these countries is questionable, ${ }^{2}$ there has been an enor-

* This article examines the Islamic Law of Bankruptcy in Sunni jurisprudence. There are two primary denominations in Islam: Sunni and Shi'i. The substantial majority of Muslims (87-90\%) in the world belong to the Sunni denomination, of which there are four schools of jurisprudence, as discussed below. Given the dominance in the most traditional Muslim communities of one of them, the Hanbali School, this article will primarily rely on its usages. While the Islamic Law of Bankruptcy according to Shi'a jurisprudence is very similar to Sunni jurisprudence, and the four Sunni Schools are also similar, there are differences. This article does not address these differences. See generally Devin J. Stewart, Islamic Legal Orthodoxy: Twelver Shitte Responses to the Sunni Legal System 1-25 (2007); see also Haider Ala Hamoudi, You Say You Want A Revolution: Interpretive Communities and the Origins of Islamic Finance, 48 VA. J. INT'L L. 249, 264-267 (2008).

** Abed Awad practices law in the New Jersey-New York area focusing on general civil litigation including complex matrimonial law, commercial law, Islamic law, and international law. Mr. Awad has frequently testified as an expert in Islamic law and the laws of various Arab countries before American courts. Mr. Awad is an Adjunct Law Professor at Rutgers Law School and Pace Law School where he teaches Islamic Jurisprudence. Robert E. Michael, a Fellow of the American Bar Foundation, is the Managing Member of Robert E. Michael \& Associates PLLC, specializing in cross-border corporate insolvencies. He is the former Chairman of the Committee on Foreign and Comparative Law of the New York City Bar Association, its current Chairman of the Subcommittee on Islamic Law, and is also an Adjunct Professor at Pace Law School.

1. Saudi Arabia is known to strictly follow Islamic law; the Quran is its Constitution. SAudi Arabia Const. art. 1. Ayatollah Khomeini instituted the "Guardianship of the Mullahs" in Iran, making Shi'a Islam its ultimate source of law. Peter Edidin, 1979: Iranian Revolution, N.Y. Times, Apr. 6, 2009, at 24. This application is not limited, however, to nations where the clergy plays an important political role. In 1980, the Egyptian Parliament amended Article 2 of the Egyptian Constitution to state that all future legislation must be based on Islamic law. Clark Benner Lombardi, Islamic Law as a Source of Constitutional Law in Egypt: The Constitution of The Sharia in a Modern Arab State, 37 Colum. J. Transnat'l L. 81, 89 n.27 (1998). The 2003 Iraqi Constitution includes a provision that Iraqi law must not violate Islamic law. IraQ Const. art. 2. Even where the law generally does not have to conform to Shari'a, various levels of Islamic law and courts are either mandatory or available to Muslims throughout the world in the area of family law and purely intraMuslim disputes.

2. See, e.g., Wael B. Hallaq, Can the Shari'a be Restored?, in Islamic Law and the Challenges of Modernity 21, 21-48 (Yvonne Yazbeck Haddad \& Barbara Freyer Stowasser eds., 2004) [hereinafter Can the Shari'a be Restored?]. "What has remained of the traditional system in the modern codes is no more than a veneer. Penal law, land law, commercial law, torts, procedural law, bankruptcy, and much else has been totally replaced by their European counterparts and supplemented, in due course, by several other codes and

\section{PUBLISHED IN COOPERATION WITH SMU DEDMAN SCHOOL OF LAW}




\title{
THE INTERNATIONAL LAWYER A QUARTERLY PUBLICATION OF THE ABA/SECTION OF INTERNATIONAL LAW
}

\author{
976 THE INTERNATIONAL LAWYER
}

mous expansion over the past twenty to thirty years of Islamic finance-public and private financial transactions which purport to be governed by Islamic law. Islamic finance and banking have grown from virtual nonexistence to constituting an approximately trilliondollar industry worldwide according to current estimates. ${ }^{3}$

It is therefore not surprising that Islamic finance has been the subject of a great deal of scholarly attention. What has not yet received the same level of exegesis is the loss side of the equation-the laws and rules of Shari'a that apply when something goes wrong. Islamic debtor-creditor and bankruptcy law is due to come into much sharper focus now that the tide lifting all ships has stopped rising and, in many areas, is going out. This article is intended to provide an exposition and analysis of the basic precepts of this side of Islamic commercial law and, in doing so, compare them to the basic elements of Western bankruptcy, notably that of the most successful and emulated one, Chapter 11 of the U.S. Bankruptcy Code. ${ }^{45}$

Above all, this article will discuss what the authors consider to be the five primary concepts that underpin or constitute the foundation of the Islamic law of bankruptcy: (1) the prohibition of riba (interest), and the concomitant lack of a theory of the time value of money; (2) the obligation to be socially responsible; (3) the divine directive to pay all of one's debts if you are able to do so, with death being the only source of a final discharge; (4) the absence of a limited liability or entity shielding concept; and (5) the absence of concepts of intangible assets and many forms of non-possessory rights common in other legal systems. These five concepts are interwoven in the fabric of Islamic commercial and financial law.

\section{What We Mean by "Classical Islamic Law"}

Shari'a is more than simply 'law' in the prescriptive sense. It is also a methodology through which a jurist engages the authoritative religious texts to ascertain divine will or intent. The outcome of this process of ascertaining divine will is the positive law. ${ }^{6}$ In that sense, Shari'a reaches its purpose as described by the meaning of its name-the Path, or the Way ${ }^{7}$-to provide guidance as to the best actions or omissions to comply with the divine will, which is the only true moral anchor of a Muslim's existence. And this principle

regulations, such as the law of corporation, copyright law, patent law, and maritime law." Id. at 24. See also Haider Ala Hamoudi, The Death of Islamic Law, 38 GA. J. INT'L \& ComP. L. 293 (explaining that, with the exception of the family law codes, the civil codes, the commercial codes, and the penal codes of most Arab countries are Western codes, which are to a great extent inconsistent with classical Islamic law).

3. Shayerah Ilias, Cong. Research Serv., RS 22931, Islamic Finance: Overview and Policy ConCERNS, 1-2 (Feb. 9, 2009).

4. 11 U.S.C. $\$ 101$ et seq. (2006).

5. See e.g., Legislative Guide on Insolvency Law, U.N. Comm'N on InT'L Trade Law, (UNCITRAL), U.N. Doc. Sales No. E.05.V.10 (2005), available at http://www.uncitral.org/pdf/english/texts/insolven/05-80 722_Ebook.pdf. The UNCITRAL Guide on Insolvency Law, issued in 2005, is modeled very closely on Chapter 11.

6. Wael B. Hallaq, Shari'a: Theory, Practice, Transformations 84 (2009) (explaining that under Islamic law, human acts that are "subject to the regulation of Sharia and therefore pronounced as law" are categorized under five norms: the forbidden, the obligatory, the recommended, the neutral, and the disapproved) [hereinafter Shari'a: Theory, Practice, Transformations].

7. Khaled Abou El Fadl, Speaking in God's Name: Islamic LaW, Authority and Women 307 (2008).

\section{PUBLISHED IN COOPERATION WITH SMU DEDMAN SCHOOL OF LAW}




\section{THE INTERNATIONAL LAWYER A QUARTERLY PUBLICATION OF THE ABA/SECTION OF INTERNATIONAL LAW}

IFLAS \& CHAPTER 11

applies in all aspects of life-whether it is a commercial transaction, a divorce settlement, or one's relationship with parents and children. ${ }^{8}$

All such juristic inquiries begin with the Quran and the Sunna. ${ }^{9}$ The Quran is the Muslim Holy Scripture. ${ }^{10}$ It is a compilation of revelations-the Word of God-received by the Prophet Mohammad from the Archangel Gabriel over a twenty-three year period beginning in 610 A.D. ${ }^{11}$ The Sunna is essentially the prophetic example embodied in the sayings and conduct of the Prophet Mohammad, as to what he promoted, what he allowed, and what he prohibited; this was preserved in a narrative form that became known as a Hadith. ${ }^{12}$

When an issue arose that was not expressly addressed in the foundational texts, or when the foundational texts were subject to varying interpretations, a methodology to utilize the foundational texts and the sanctioned interpretive tools evolved into a sophisticated jurisprudential system. ${ }^{13}$ Without an ecclesiastical hierarchy or a Sanhedrin-type court, ${ }^{14}$ there was no institutional monopoly over divine truth or divine intent by any scholar. This environment fostered and actually encouraged different interpretations of the law. This process of acceptance of different interpretations developed into full-fledged Schools of Law or madhabeb. ${ }^{15}$ This "legal pluralism," according to Hallaq, explained Shari'a's "flexibility and adaptability to different societies and regions." 16 It is believed that dozens or even hundreds of different scholars established their own Schools of Law with students

8. Shari'a: Theory, Practice, Transformations, supra note 6. See generally Wael B. Hallaq, An Introduction to Islamic LaW 5-31 (2009) [hereinafter Introduction]; Mohammad Hashim Kamali, Principles of Islamic Jurisprudence 1-2 (2003). See also El Fadl, supra note 7. "Sharia Lit., water source, the way, the path; Islamic theology and law: the path or way given by God to human beings, the path by which human beings search God's Will. Commonly misinterpreted as 'Islamic law,' Shariah carries a much broader meaning as the sum total of categorizations of all human actions .... Shariah is not restricted to positive law per se but includes moral and ethical values, and the jurisprudential process, itself." $I d$.

9. Kamali, supra note 8 , at 16,58 .

10. Id.

11. Much like the Jewish Torah, of which the Quran declares itself to be the second amendment (the Christian Bible being the first amendment), the Quran includes approximately 500 verses with legal relevance. Wael B. Hallaq, A History of Islamic Legal Theories 3 (2002) [hereinafter History]. "Among the multitude of exhortations and prescriptions found in the Quran, there are many legal and quasilegal stipulations. For example, legislation was introduced in select matters of ritual, alms-tax, property and treatment of orphans, inheritance, usury, consumption of alcohol, marriage, divorce, sexual intercourse, adultery, theft, homicide, and the like. Muslim jurists and modern scholars are in agreement that the Quran contains some 500 verses with legal content." Id.

12. Kamali, supra note 8, at 58-59; Introduction, supra note 8, at 16-18.

13. Shari'a: Theory, Practice, Transformations, supra note 6 , at 59-60.

14. Again, this is the Sunni system. Shi'a Islam is hierarchical and has authoritative rulings by the Imams. Hussein Abdulwaheed Amin, The Origins of The Sunni/Shia Split in Islam, Islam for Today, http://www. islamfortoday.com/shia.htm (last visited Oct. 4, 2010). Under Shi'i jurisprudence, there are also the binding legal rulings and traditions of the Imams, the prophetic successors to Muhammad, of which there were either twelve (believed by the majority Twelvers), seven or five, depending upon the sect. In addition, the Shi'i jurists argue that, unlike the Sunnis, they rely more on reason $(a q l)$ to interpret the law. Id. See generally STEWART, supra note*; see also Hamoudi, supra note*.

15. Introduction, supra note 8, at 31-37; see also Wael B. Hallaq, The Origins and Evolution of IsLAMic LAW 150-77 (2005) (explaining how the evolution of the schools from a circle of students with their teacher to personal schools to doctrinal schools by the 9th century) [hereinafter Origins and EvOLUTION].

16. Introduction, supra note 8, at 27.

\section{PUBLISHED IN COOPERATION WITH SMU DEDMAN SCHOOL OF LAW}




\title{
THE INTERNATIONAL LAWYER A QUARTERLY PUBLICATION OF THE ABA/SECTION OF INTERNATIONAL LAW
}

\author{
978 THE INTERNATIONAL LAWYER
}

and followers. ${ }^{17}$ Over time and by the 11th or 12th century, these schools went through a process of consolidation and/or extinction due to objective political, social, economic, and intellectual factors which led to only four surviving schools in Sunni law ${ }^{18}$-Hanafi, Maliki, Shafi'i, and Hanbali19.

After the two primary sources of Islamic law, the Quran and the Sunna, the two main secondary sources of Islamic law developed by the madhabeb are: (1) ijma (consensus of the ulema, the scholars and jurists, and sometimes the entire community), and (2) qiyas ${ }^{20}$ (reasoning by analogy to one of the higher sources).21 Other sources of Islamic law such as istibsan (juristic preference), istishab (presumption of the continuity or permanence in juristic reasoning), istislab (public interest as a source of law) are tertiary. ${ }^{22}$ The process of analytical legal reasoning that is used to deduce or derive the law from the primary sources is called "ijtihad." Ijtihad literally means to exert, strive, and/or endeavor. A jurist would utilize ijtihad by engaging and exerting his independent intellectual faculties and reasoning based on the express scriptures and/or spirit of the scriptures to reach a legal or theological ruling. ${ }^{23}$ A key element of the process is that only properly trained jurists were qualified to interpret the sources, and thus determine the law. Therefore the holder(s) of political powers were not competent to create law. In other words, Shari'a "was not the product of Islamic government" and was to a great extent independent of the ruler. ${ }^{24}$

Because the Shari'a governs every aspect of an observant Muslim's life, including commercial and financial dealings, the underpinnings of Islamic finance and commercial transactions and business relationships are also ruled by the same degree of honesty, good faith, an eye to fairness, social responsibility, and equity as interpersonal relations. In particular, the Quran and the Prophet Mohammed were very concerned about protecting the poor in

17. Origins and Evolution, supra note 15. See generally 4 Christopher Melchert, The FormaTion of the Sunni Schools of Law, 9тh-10th Centuries C.E. 198-204 (1997).

18. Origins and Evolution, supra note 15, at 167-72. See generally Shari'a: Theory, Practice, Transformations, supra note 6 (providing an authoritative history of the development of Islamic law and jurisprudence).

19. The geographic allocation of these schools is generally as follows: The Arab Persian Gulf countries follow the Hanbali School of Law; North Africa, such as Morocco, Tunisia and Algeria, follow the Maliki School of Law; Sunni Muslims in Turkey, Iraq, Egypt, Syria, India, Pakistan and Afghanistan, as well as Central Asia, tend to follow the Hanafi School of Law. Palestine and East Africa, Indonesia and Southeast Asia predominantly follow the Shafi'i School of Law. As a result of the fact that the majority of Islamic finance is originating out of the Gulf countries, the authors' examination of the Islamic law of Bankruptcy relies on the most authoritative Hanbali treatise on Islamic Law of Bankruptcy. See generally Islam, in ENCYClopedia of Politics and Religion 383-93 (Robert Wuthnow ed., 1998) [hereinafter Islam]; Hans VisSer, Islamic Finance: Principles and Practice 15-16 (2009); Ilias, supra note 3, at 1.

20. There are some differences between Shii jurisprudence and Sunni jurisprudence.

21. INTRODUCTION, supra note 8 , at 21-27.

22. Id. See generally Kamali, supra note 8; History, supra note 11 (providing a detailed discussion on the sources of Islamic law).

23. EL FADL, supra note 7, at 301 ("ijtihad Lit. exertion. The process of exerting one's utmost in an effort to deduce laws from sources in unprecedented cases. Novel or original legal solutions, the effort of a jurist in searching for and deducing the correct law.”). See also History, supra note 11, at 117-21.

24. Introduction, supra note 8, at 35-36. "Thus, legal authority in Islam . . w was in the persons of the individual jurists (be they laymen or, on occasion, caliphs) that authority resided . . [d] evolving as it did upon the individual jurists who were active in study circles, legal authority did not reside in the government or ruler, and this was a prime factor in the rise of the madhhab. Whereas law-as a legislated system-was often "state"-based in other imperial and complex civilizations, in Islam the ruling powers had, until the dawn of modernity, almost nothing to do with the production and promulgation of legal knowledge or law." Id.

\section{PUBLISHED IN COOPERATION WITH SMU DEDMAN SCHOOL OF LAW}




\section{THE INTERNATIONAL LAWYER A QUARTERLY PUBLICATION OF THE ABA/SECTION OF INTERNATIONAL LAW}

IFLAS \& CHAPTER 11

society from exploitation by the wealthy, especially from moneylenders. ${ }^{25}$ Moreover, the Prophet instituted certain regulations intent on acting as market regulation to make sure that wealth was not concentrated in a small group ${ }^{26}$ and that necessities in society were not subject to speculation due to scarcity. ${ }^{27}$

During the Middle Ages in Western Europe, when Islamic military conquests were no longer the dynamic driver of Muslim society, ${ }^{28}$ Muslim jurists expanded and rationalized Islamic law. ${ }^{29}$ This full-bodied Shari'a occupied the vacuum resulting from the disappearance of the Roman Empire and its very sophisticated legal system. ${ }^{30}$ Beginning with the functional replacement of the Caliphates by the Ottoman Empire in the 14th century and culminating with the piecemeal European colonial conquests of the majority of the Muslim world and the nation-state building post colonialism that occurred from the 18th through the late 20th centuries, governance by "Classical Islamic law" was suddenly and abruptly ${ }^{31}$ replaced by various national legal systems, increasingly based upon English common law or French civil law. ${ }^{32}$ Shari'a remained primarily as the local law limited to governing family and religious disputes. ${ }^{33}$

Because "Islamic" finance is purported to be governed by classical Islamic law, this article therefore is intended to be part of the effort to determine how classical Islamic law addressed debtor-creditor law in the Golden Age of Islam to inform how it would apply today. The laws and practices we refer to in this article are therefore not those of today's Muslim nation-states, but those of the pre-modern Muslim period.

25. S.M. Ghazanfar \& Azim Islahi, Explorations in Medieval Arab-Islamic Economic Thought: Some Aspects of Ibn Qayyim's Economics, in Medieval Islamic Eсопомic Thоught 128-41 (S.M. Ghazanfar ed., 2003). The prohibition of usury is "absolute, as per the scriptures, some argument (aside from 'sinfulness') being the possibility of economic exploitation and injustice in transactions." Id. at 134.

26. The Divine directive to give charity is: "So that wealth does not circulate only among your rich." Quran 59:8.

27. See ILIAs, supra note 3, at 1; see generally Mohammad Fadel, Ribâ, Efficiency And Prudential Regulation: Preliminary Thoughts, 25 WIS. INT'L L.J. 655 (2008); Mahmoud A. El-Gamal, An Economic Explication of the Probibition of Riba in Classical Islamic Furisprudence (2001), available at http://www.ruf.rice.edu/ elgamal/files/ riba.pdf.

28. The Muslim, or Moorish, armies were stopped in the West in 732 A.D. near Poitiers, in the Southwest of France (by Charlemagne's grandfather). The eastward expansion was equally rapid. The conquests of the Arab Muslims by the Seljuk Turks during the 11th and 12th Centuries heralded the beginning of the end of what is called the Pax Islamica, or the Islamic Golden Age. History of Seljuk Turks, Turkey for You, http:// www.turkeyforyou.com/travel_turkey_seljuks (last visited Oct. 5, 2010).

29. Origins and Evolution, supra note 15, at 167-72. See generally MELCHERT, supra note 17.

30. Origins AND Evolution, supra note 15, at 167-72.

31. See generally Can the Shari'a be Restored?, supra note 2 (demonstrating that the colonialist project caused a rupture in Islamic legal thinking and the Islamic legal institution effectively destroying it overnight). "[T]he demise of the shari'a was ensured by the strategy of 'demolish and replace': the weakening and final collapse of educational waqfs, the madrasa, positive Islamic law, and the shari'a court was made collateral, diachronically correlational, and causally conjoined with the introduction of state finance (or, to put it more accurately, finance through the controlling agency of the state), Western-style law schools, European codes, and European court system. If law were to represent the entire spectrum of Islamic culture, it would not be an exaggeration to state that by the middle of the twentieth century, nothing in Islam was saved from a distinctly determined and omnipotent European hegemony." Id. at 24.

32. See id.; see also Hamoudi, supra note *.

33. Id. 


\title{
THE INTERNATIONAL LAWYER A QUARTERLY PUBLICATION OF THE ABA/SECTION OF INTERNATIONAL LAW
}

\author{
980 THE INTERNATIONAL LAWYER
}

\section{The Conceptual Framework of the Islamic Law of Bankruptcy ${ }^{34}$}

The Arabic word iflas means bankruptcy. ${ }^{35}$ It covers both the modern senses of (i) balance sheet insolvency, when an entity's assets are less than its liabilities; and (ii) income statement or cash flow insolvency, when an entity has insufficient liquid or monetizable assets to pay its debts as they come due. The Arabic word muflis means a bankrupt entity, whether male or female or business enterprise. ${ }^{36}$ And once one is a muflis, there are only two ways that status ends: full repayment of all unforgiven debts or death.

The primary textual authority for the Islamic law of bankruptcy is in the ultimate source of Shari'a, the Quran, at verse 2:280. It is commonly translated as: "If a person is in difficulties, let there be respite until a time of ease. And if you give freely [i.e., if you forgive the debt voluntarily] it would be better for you, if only you knew." 37

As this verse makes clear, at the heart of the Islamic law of bankruptcy are the principles underlying all of the Shari'a: social responsibility and charity. This forceful divine, but not compulsory, recommendation to be kind to one's debtor, is balanced by the Quranic verse that compels a Muslim to repay one's debts—-making it a sin and not just a legal obligation not to pay off all of your debts that you have the capacity to repay: "O you who believe, you shall fulfill your covenants." 38

In other words, not just creditors are compelled to exercise honest dealing and scrupulous fairness. This is a divine instruction to fulfill one's contracts. To make this point, the jurists frequently cite a tradition from the Prophet that stated that a debtor delaying paying a debt or an obligation without a valid excuse, even to a wealthy person, is unjust. ${ }^{39}$ Flowing from this, debt is frowned upon in Muslim ethical and moral perceptions. It is believed that the Prophet Muhammad had told his believers that the soul of the Muslim will be suspended with his debts and freed only when his debts are satisfied.40

Contextually, theologically, and philosophically, there is a direct link between the Islamic law of bankruptcy and the Islamic law of finance. Both are tied to social responsibility and economic equity. In fact, the verse in the Quran that outlaws all forms of riba

34. As noted earlier, our exposition of the Islamic law of debtor-creditor and bankruptcy is according to the Hanbali School. We primarily rely upon one of the most authoritative Hanbali law treatises from the 12th Century: Ibn Qudamah's al-Mughni. It is a commentary on a famous 10th century Hanbali treatise titled alMukhtasar, written by a renowned 10th century jurist named Abu al-Qasim Ibn al-Hussien ibn Abdallah alKharqi. Al-Mughni continues to be regularly consulted until today by Saudi Arabia courts. IBN QUDAMAH, 7 Munaffaq al-Din Abu Muhammad Abd Allah Ibn Ahmad Ibn Muhammad, Al-Mughni fi fiqh imAM AL SUNNAH AHMAD IBN hanbal al SHaybani [THE Nome of THE BigGest Books in (Hanbali) IsLAMic SCHOOL] 5-6 (abdallah ibn abd al muhsen al turki and abdel fatah muhammed al-hilu eds., 1988).

35. The Hans Wehr Dictionary of Modern Arabic 850 (JM Cowan ed., 1994).

36. Ibn Qudamah, 1 Muwaffaq al-Din Abu Muhammad Abd Allah Ibn Ahmad Ibn Muhammad, AL-Mughni Fi FIQH IMAM AL SUNNAH AHMAD IBN HANBAL AL SHAYBANI 536-37 (abdallah ibn abd al muhsen al turki and abdel fatah muhammed al-hilu eds., 1988); see also Abdassamad Clarke, Fulus, World Islamic Mint, Aug. 22, 2010, http://www.islamicmint.com/news_articles/articles/fulus.html.

37. Quran 2:280. All translations of the Quran are from Tarif Khalidi's recent translation: The Quran (Penguin Classics, 2008). Unless otherwise noted, all other translations from Arabic to English here are by Abed Awad.

38. Quran 5:1.

39. Fath al-Baari Sharh Saheeh Bukhari, Traditions, http://www.al-eman.com/hadeeth/viewchp.asp?BID= $12 \& \mathrm{CID}=217$.

40. The Basic Rules of Islamic Funerals, Islamic Center of Raleigh, http://islam1.org/iar/imam/archives/2004/ 12/30/the_basic_rules_of_islamic_funerals.php (last visited Oct. 12, 2010).

\section{PUBLISHED IN COOPERATION WITH SMU DEDMAN SCHOOL OF LAW}




\section{THE INTERNATIONAL LAWYER A QUARTERLY PUBLICATION OF THE ABA/SECTION OF INTERNATIONAL LAW}

IFLAS \& CHAPTER 11

(discussed below) follows immediately the verses that require Muslims to be charitable. ${ }^{41}$ The two concepts are then blended together: "Those who consume usury (riba) shall not rise from the dead ... [t] his is because they allege that commerce is the same as usury (riba). But God has made commerce licit and usury illicit . . . G God annuls usury and augments free gifts." 42 The very next paragraph includes the verse quoted above that establishes the jurisprudential predicate for Islamic bankruptcy law. ${ }^{43}$ Thus, both lending and repaying are interwoven with powerful divine compulsions to be charitable and compassionate. Additionally, both are dynamically impacted by the static concept of money as a means of exchange and storage of value-a commodity that facilitates commerce, rather than something of intrinsic value such as capital. ${ }^{44}$ The first element is the consistent requirement for fair treatment and avoidance of punishment for an inability to pay one's debts due to economic hardship.

The second element is manifested, and also will be discussed below, in the fact that there is no equivalent to discharge of debts under Islamic law. This harsh rule, at first seemingly inconsistent with a charitable imperative, is the natural extension of the fact that Muslims are directed to fulfill their obligations and promises.

It is also consistent with the lack of interest on money or increase of the amount of a debt due to delayed payment. Without the debt increasing over time, the debtor has a lifetime to whittle it down. With no risk value of money creating high interest rates to reflect the inability of the insolvent debtor to repay the debt on time, the amount of the debt can only go down over time, both in real and economic terms. Put another way, if you can pay it back at any time in your life, you must. But if you cannot, there is no moral or legal requirement or penalty. In sum, a debt owed to someone must be paid if possible. Muslims must fulfill their promises and obligations both to God and to man.

These key tenets of no discharge and social responsibility are prescriptive elements of Islamic law that clearly differentiate it from Western law. In addition, there are three basic elements of Post-Enlightenment Western law that underlie all modern capitalist systems that are not a part of the current mainstream Shari'a, creating critical differences: (i) the time and risk value of money, as discussed above, (ii) entity-shielding, and (iii) intangible and non-possessory assets and rights. ${ }^{45}$

41. Quran 2:275.

42. Quran 2:276

43. The supremacy of the Federal Bankruptcy Code and the exclusive jurisdiction over bankruptcy of federal courts in the United States are based on a similar thin reed. It is all based solely on Article 1, Section 8, Clause 4 of the U.S. Constitution, which authorizes Congress to enact "uniform Laws on the subject of bankruptcies throughout the United States." U.S. ConsT. art. I, $\$ 8$, cl. 4.

44. S.M. Ghazanfar \& A. Azim Islahi, Economic Thought of an Arab Scholastic: Abu Hamid al-Ghazali, in Medieval Islamic Economic Thought 23-44 (S.M. Ghazanfar, ed. 2003) (quoting al-Ghazali-a renowned 12 th century jurist). "When someone is trading in dirhams and dinars themselves, he is making them as his goal, which is contrary to their functions. Money is not created to earn money, and doing so is a transgression. The two kinds of money are means to acquire other things; they are not meant for themselves .... If a person is permitted to sell (or exchange), money with money (for gain), then such transactions will become his goal, and thus money will be imprisoned and hoarded. Imprisonment of the ruler or postman is a transgression, for then they are prevented from performing their functions; same with money." Id. at 37. See also Robert E. Michael, Address to the Ambassadorial Level Meeting of the Organization of the Islamic Conference in the United Nations, Islamic Finance in Relation to Capitalism and Socialism (Apr. 6, 2010), available at http://www.jdsupra.com/post/documentViewer.aspx?fid=4ec3e621-e2c1-4ab0-a2a2-798112b92801.

45. Michael, supra note 44. 


\title{
THE INTERNATIONAL LAWYER A QUARTERLY PUBLICATION OF THE ABA/SECTION OF INTERNATIONAL LAW
}

\author{
982 THE INTERNATIONAL LAWYER
}

"The time value of money is the opportunity value of having control over, and use of, the money for the period involved ...."46 Its common measure is the inflation rate. The risk value of money is more complex, having two components-the risk of it not being paid back and the risk of it not being paid for reasons having nothing to do with the purpose for which it was provided. ${ }^{47}$ Classical Islamic law certainly contemplated and approved of the former, assuming risk profit or loss in return for one's investment of value. It did not have the latter-the risk of not being repaid for other reasons. This is the direct result of the fact that in Islamic law, money is viewed solely as either a commodity itself or as a universal unit of exchange. ${ }^{48}$ This has sweeping consequences for Islamic debtor-creditor law. ${ }^{49}$

The purest expression of this distinction is in the current mainstream Muslim position that interprets the Quranic riba to include a complete prohibition of the charging or paying of interest. The root of the word riba literally means, "increase." 50 "Without interest, a debt of $\$ 1,000$ incurred today must only be repaid with $\$ 1,000$ in the future, with no accounting for any value to the use of the funds in between." 51 Strictly speaking, it is prohibited to take a loan and pay it back with interest. ${ }^{52}$

We recognize that an intense debate has developed in Islamic scholarly and financial circles over the meaning of riba. Certainly, mainstream Orthodox Muslims today agree that all forms of conventional "interest" are the same as the forbidden riba. Disputes with this today are based on a variety of theories beyond the scope of this article but generally focus on conflating interest with inflation of value over time and that riba only applied to certain commodities, and/or riba is usury note interest. ${ }^{33} \mathrm{We}$ are deconstructing interest to limit it to the application of asset appreciation to money as a means for storage of value itself and as a unit of exchange. This article does not refer to money as a commodity or as a replacement for or price of the tangible asset into which it may have been exchanged. With this understanding, there is no time value of money in the Western understanding of capital.

Thus Shari'a accords no value to the ability to utilize the money in the meantime. In other words, it is considered unlawful riba-unethical and sinful-to either lend or borrow a sum certain ("X") today, for example $\$ 1,000$ dollars, to be paid back in one year at a greater sum ("X+Y"), say $\$ 1,100$ dollars. On the other hand, when money isn't involved, there is a concept of "time value" to tangible assets recognized in Islamic law that is identical to that of Western capitalism's inflation and asset appreciation. For example, it is perfectly acceptable for an owner of a building to sell it to a buyer either for \$1,000 dollars

\footnotetext{
46. Id.

47. Id.

48. Ghazanfar \& Islahi, supra note 44 , at $36-37$.

49. Id.

50. Among pre-Islamic legal systems of the region, Jewish law prohibited the charging of interest by a Jewish lender to a Jewish borrower; while Roman law regulated interest, setting rates above which it became usury. Compare Islamic Bank, IsLAMIC ECONOMICS, available at http://islamic-world.net/economics/ib_intro. htm (last visited Oct. 17, 2010) (prohibiting usury), with Ismail Aminuddin, Historical View on Usury ("riba"), IsLAMIC BANKING WAY Nov. 18, 2009, http://www.islamicbankingway.com/2009/11/6-historical-view-onusury-riba.html (allowing usury).

51. Michael, supra note 44 .

52. See generally Fadel, supra note 27; Ghazanfar \& Islahi, supra note 44, at 36-37.

53. Fadel, supra note 27.
}

\section{PUBLISHED IN COOPERATION WITH SMU DEDMAN SCHOOL OF LAW}




\section{THE INTERNATIONAL LAWYER A QUARTERLY PUBLICATION OF THE ABA/SECTION OF INTERNATIONAL LAW}

IFLAS \& CHAPTER 11

cash at closing or $\$ 1,100$ over 12 months ${ }^{54}$-recognizing both the increase in value of the house and the service provided by the seller to allow the buyer to have more time to pay him. ${ }^{55}$

This explains how the prohibition of riba did not completely block capital formation or cripple commerce in societies governed by Shari'a. ${ }^{56}$ Thus, when we assert the lack of "time value of money" in the Shari'a, we are strictly referring to the lack of an allocation of an increase (the root meaning of riba) in value of money as a means to store value itself. This is perfectly consistent with the fact that under Orthodox Islamic law, precious metals as a commodity are allowed to increase in value, whether in the form of currency, jewelry, or ingots. ${ }^{57}$ While this apparent "lack" restricts capital formation by hampering low-risk (i.e., non-equity level) investment, it is critical to harmonizing the obligation to repay one's debts and a charitable bankruptcy system. It is the perfect bridge between the two.

While the charging of interest on money is affirmatively rejected by leading Islamic commentators, entity-shielding, ${ }^{58}$ which has its most familiar forms in the so-called cor-

54. Michael, supra note 44.

55. See Abraham Udovitch, Credit as a Means of Investment, 87 J. Of THE Am. Oriental Soc'y 260, 262 (quoting Sarakhsi-a Hanafi authority that "a thing is sold on credit for a larger sum than it would be sold for in cash").

56. Id. "The difference in price between a credit and cash sale also helps explain why the prohibition against usury, to the extent that it was observed (which was probably considerable), did not exercise any crippling restriction on the conduct of commerce. For, while the difference in the price for which one sells on credit and the price for which one sells for cash does not formally or legally constitute interest, it does fulfill, from the point of view of its economic function, the same role as interest by providing a return to the creditor for the risks involved in the transaction, and compensating him for the absence of his capital." Id.

57. For the mainstream current view that interest is riba see Yousef al-Qardawi, Fatwa, http://www. qaradawi.net/site/topics/article.asp?cu_no=2\&item_no=377\&version=1\&template_id=8\&parent_id=12 (holding that "The interest that the depositor receives from the bank is unlawful riba. Riba is every conditioned increase on principal; that is, what is taken without trade or work, as an increase on the principal, is riba."). For the position that Islamic law permits fixed interest-as long as it is not usurious-and it does not constitute the prohibited riba in the Quran, see Rafic Yunus Al-Masri, Are All Forms of Interest Probibited?, 17 J. OF KING Abdelaziz U. on Islamic Econ., 37, 37-42 (2004) ("When a Muslim extends an interest-free loan (qard hasan), Allah rewards him for such deed. Had he not foregone the 'interest rate', he would have not been eligible for such a divine reward. A clearer case is that of a Muslim selling a commodity on credit, he can obtain a higher price for the commodity sold on credit than its immediate cash price. Thus there is interest involved in return for the factor of time or deferment, which is permissible, and which is also the exact definition of interest. [...] It is on these grounds that jurists mentioned that time has a share in the price or; in other words, it is permissible to increase the price (of an article of trade) in return for postponement of the time of payment, which means that there is a share in the price for the time factor."). Id.

58. The concept of the corporate veil and limited liability entities, which evolved first with the societas publicanorum in Rome around the 4th century B.C., disappeared when Rome fell. It was not until the Genovese proto-stock companies developed around the 15th century, and the Dutch and English stock companies were created in the early 17 th century that the true limited liability entity concept re-emerged in the West. Henry Hansmann, Reinier Kraakman \& Richard Squire, Law and the Rise of the Firm 25-26 (N.Y. Univ. Stern Sch. of Bus. Working Paper, 2005), available at http://www.stern.nyu.edu/eco/wkpapers/Hansmann.pdf. Full-blown entity shielding really did not develop, however, until the latter half of 19 th century in Britain and the early 20th century in the United States. There is a very interesting bridge and cross-over between the commenda joint venture contractual relationship of the Lex Mercatoria and the possibly pre-Islamic, and certainly fully Islamic mudaraba partnership to which many attribute its origin. Both originally involved an investor with liability limited to his investment and a voyager/trader/merchant who was exposed to personal liability for incurring debts exceeding the enterprise's assets. Lost in time, however, is whether the limited liability aspect of the investor was based on a recognized legal rule or simple practicality. See generally Ron Harris, The Institutional Dynamics of Early Modern Eurasian Trade: The Commenda and the Corporation (Tel Aviv

\section{PUBLISHED IN COOPERATION WITH SMU DEDMAN SCHOOL OF LAW}




\title{
THE INTERNATIONAL LAWYER A QUARTERLY PUBLICATION OF THE ABA/SECTION OF INTERNATIONAL LAW
}

\author{
984 THE INTERNATIONAL LAWYER
}

porate veil and all forms of limited liability partnerships and companies, simply has never been a part of the Shari'a. ${ }^{99}$ Consequently, the corporate form never developed in Islamic law, nor did other more modern vehicles such as limited liability partnerships or companies. All personal and economic activities are conducted through either direct proprietary ownership or one of the "nominate" forms of partnerships that were approved by the jurists.

In some ways, this is both similar to and associated with the lack of such personal property rights that are common in other economic systems, such as intellectual property rights and the equity of redemption, or such key accounting concepts as goodwill and deferred income and expenses. As a result, or at least for the same reason, classical Islamic law also did not develop the concept of non-possessory liens and security interests. Possessory liens of personalty are the only ones recognized in the ordinary course; real property rights are limited as well.60 The critical exception is a specific right based on an explicit Hadith to seek recovery of a vendor's goods that were delivered to a debtor on credit and not paid for, as discussed below.

The almost exclusive focus on things that one could touch and see is not surprising given the temporal framework of the development of classical Islamic law with its adversity to uncertainty and speculation. As with so many other areas, Roman law had in fact developed many of these concepts, but they were not resuscitated until nearly 1,000 years after Rome fell. In many ways, classical Islamic law was far ahead of the West. For example, the Shari'a recognizes the usufruct of real property and leaseholds (Ijara) and allowed common ownership through a partnership. ${ }^{61}$ Joint tenancies of real estate without the four unities (i.e., owned by individuals without completely the same interests) were not a feature of English common law until after the 15th century. ${ }^{62}$

With these basics in the background of any analysis involving Islamic commercial law, we can turn to the treatment of defaulting debtors.

Univ. Working Paper, 2008), available at http://papers.ssrn.com/sol3/papers.cfm?abstract_id=1294095 (discussing both the commenda and its relationship to the mudaraba partnership).

59. See generally Авraham L. Udovitch, Partnership and Profit in Medieval Islam (1970). "In Hanafi law, and indeed in all of Islamic law, the liability in all partnerships is unlimited. In all Islamic partnerships, the partners are liable in proportion to their share of the total investment. There is no limit whatsoever on the amount of the partnership's liability. Each partner is responsible for his share of the partnership's indebtedness regardless of what it amounts to, or by how much it exceeds the value of his own share of the company's assets." Id. at 41. However, as noted above and discussed below, the mudaraba partnership arguably does function as a form of limited partnership.

60. Mark J. Sundahl, Iraq, Secured Transaction, and the Promise of Islamic Law, 40 Vand. J. Transnat'L L. 1301, 1312-33 (2007) (providing the Islamic law traditional view that possession is required in pledges but arguing that such requirement is not expressly supported in the Quran).

61. See, e.g., Mansour b. Yunus b. Idris Buhuti, aL-Rawd aL-Murbi bi-Sharh Zad aL-Mustaqn 319 (2002) [hereinafter AL-RAWD]. "Partnership ... is of two types. [The first type is] Partnership in Ownership, which is where [more than one person] join in a right, such as proof of ownership in real estate or a benefit for two or more persons." Id. This form of partnership is akin to the common law concept of joint ownership in real estate without the right of survivorship. Id.

62. See, e.g., Etoll v. Etoll (In re Etoll), No. 08-23238 (Bankr. D. N.J., Mar. 5, 2010), available at http://www. leagle.com/unsecure/page.htm? shortname=inbco20100305642.

\section{PUBLISHED IN COOPERATION WITH SMU DEDMAN SCHOOL OF LAW}




\section{THE INTERNATIONAL LAWYER A QUARTERLY PUBLICATION OF THE ABA/SECTION OF INTERNATIONAL LAW}

IFLAS \& CHAPTER 11

\section{The Debtors}

Muslim jurists defined a person to be a muflis as one whose debts exceed his assets and/ or a person whose current expenditures exceed his current revenues. ${ }^{63}$ As noted above, Islamic debtor-creditor law made no distinction between balance sheet insolvency (assets minus liabilities) and liquidity insolvency (insufficient cash flow). ${ }^{64}$ This is a natural consequence of the basic elements noted, which included the absence in Shari'a of either the time value of money or most intangible assets, since tangible assets could be presumed to be readily able to be liquidated. Thus, because the debtor's assets could be utilized to pay off his debts, there was no need to distinguish between asset shortfalls and cash flow shortfalls. A debtor becomes a muflis when the debtor defaults and the creditor or creditors move to collect.

Women under Islamic law have full legal capacity to contract, own property, earn income, and inherit. ${ }^{65}$ Therefore, women can also become bankrupt. As such, laws apply identically to women as to men. In addition, this rule also applies to businesses. There is no distinction between a business bankruptcy and an individual bankruptcy. As noted above, limited liability companies or corporations with limited liability did not develop under Islamic law. 66 Therefore, most business relationships throughout Islamic history (other than straightforward vendor-customer merchant ones) were different types of partnerships and joint ventures.

\section{Personal Bankruptcy versus Commercial Bankruptcy}

As noted above, there is no distinction in classical Islamic bankruptcy law between personal and commercial bankruptcies. This is entirely consistent with the related elements of a continuing duty to pay one's debts and the lack of the development of limited liability, entity-shielded, business vehicles, such as the corporation. As a result, the liabilities of the business enterprise would also be the obligations of the individual owner, or the partners in the partnership.

63. Ibn Qudamah, 1 Muwaffaq al-Din Abu Muhammad Abd Allah Ibn Ahmad Ibn Muhammad, Al-Mughni Fi FiQH IMAM AL SUNNAH AHMAD IBN HANbal aL SHAYbani 536-38 (abdallah ibn abd al muhsen al turki and abdel fatah muhammed al-hilu eds., 1988); Clarke, supra note 36.

64. Ibn Qudamah, supra note 36; Abd Al Awal Abdin Muhammad Basyuni, Athar al-iflas fi istifa AL-DAININ HUQUQAHUM MIN AL-TAFLISAH: DIRASAH MUQARANAH FI AL-FIQH AL-ISLAMI WA-AL-QANUM aL-Wad'i [The Effects of Bankruptcy to Satisfy the Creditors' Rights of the Bankruptcy: A Comparative study of Islamic Jurisprudence and Positive Law] 32, 35, 39 (2008).

65. See generally Azizah Yahia al-Hibri, Muslim Women's Rights In The Global Village: Challenges and Opportunities, 15 J. L. \& RELigION 37, 46-47 (2001). "[T]he Muslim woman is an independent legal entity, not lost through marriage. A Muslim woman retains her own name after marriage. She also retains her financial independence. She can own property in her own right whether she is married or single, and no one, not even her husband, may access her funds or properties, or demand any form of financial support from her. Any money or property of her own that the wife gives her husband, even if she is richer than he, is regarded as a loan unless she expressly specifies otherwise." Id. See generally Yossef Rapaport, Marriage, Money AND Divorce in Medieval Islamic Society (2007).

66. The closest thing to an artificial legal entity that Islamic law developed was the waqf, an endowment or trust that operated only for charities or businesses.

\section{PUBLISHED IN COOPERATION WITH SMU DEDMAN SCHOOL OF LAW}




\section{THE INTERNATIONAL LAWYER A QUARTERLY PUBLICATION OF THE ABA/SECTION OF INTERNATIONAL LAW}

There are several types of partnership structures under Islamic law. ${ }^{67}$ The inan partnership is one of the most common: it is a limited investment vehicle-limited in duration or project. In it, only the amount a partner contributes to the partnership becomes part of the partnership's property. His other assets are not part of the partnership. ${ }^{68}$ Although the partners are each other's agent to the extent of the partnership's assets and purpose, they are not each other's guarantors. ${ }^{69}$ The partners in an inan partnership are severally, not jointly, liable to third parties. ${ }^{70}$ This means that the third party must seek payment of his entire claim directly from the partner with whom he dealt. After the partner has paid the third party claim, the paying partner would be entitled to seek the appropriate contribution from the other partner. In sum, within the partnership, they are jointly liable for all liabilities arising out of the partnership enterprise. ${ }^{71}$

None of the partners have the right to take on any debt that would exceed the partnership's agreed assets. If they do, the partner that did not authorize the additional credit is not liable for anything in excess of his original agreed upon earmarked contribution to the partnership fund-either to the other partners or to the third party creditor. ${ }^{72}$

If none of the partners have willfully undertaken such an excess obligation or debt, but for unforeseen circumstances (such as a casualty loss) the partnership becomes liable for a debt in excess of its assets, all of the partners will be liable to make up the deficiency according to their ownership interest. As between each other and the inan itself, their liability will be limited to their proportionate interest in the partnership as per the contract or verbal agreement of the partners. ${ }^{73}$ Although the partners can agree to distribute profits disproportionate to their original investment, they are not permitted to allocate the liabilities disproportionately. ${ }^{74}$

A mufawada partnership is an agency partnership-the members of the agency contract are each other's agents and guarantors. ${ }^{75}$ All partners should be equal in capital investment and profit sharing. They are liable jointly and severally for any obligations to third parties not repaid by the mufawada assets. ${ }^{76}$ In the event that such several liability causes a partner to make a payment in excess of his personal investment in the mufawada assets, the partner would then have a right to seek reimbursement ("contribution") from the other partners for the amount they paid to the third party creditor(s) in excess of their investment percentage. ${ }^{77}$ The exception to this joint and several liability is that partners are not liable for the criminal acts, wrongful appropriation of another's property, and purely per-

67. AL-RAWD, supra note 61. For a good introduction regarding the differences, see generally IBN RUSHD, Bidayat al Mujtahid wa Nihayat al Muqtasid [The Distinguished Jurist's Primer] 301 (Imran Ahsan Khan Nyazee trans., 1996) (2000).

68. See Mansour b. Yunus b. Idris Buhuti, 6 Kashaf al Qina an Matn al-iqna $534-35$ (1999) [hereinafter KASHAF]; UDOVITCH, supra note 59, at 41.

69. AL-RAWD, supra note 61, at 319-20; see also KASHAF, supra note 68, at 533-35; UDOvitCH, supra note 59 , at $119,135$.

70. AL-RAWD, supra note 61 , at 320 .

71. Id. at 319-320; KASHAF, supra note 68, at 533-35; see also UdOvitch, supra note 59, at 135.

72. AL-RAWD, supra note 61, at 320; UDOVITCH, supra note 59, at 135.

73. AL-RAWD, supra note 61, at 320,322; see also KASHAF, supra note 68, at 533-35; Udovitch, supra note 59 , at 135 .

74. KASHAF, supra note 68 , at 532-33.

75. AL-RAWD, supra note 61, at 322; KASHAF, supra note 68, at 564; UDOVITCH, supra note 59, at 99-100.

76. KASHAF, supra note 68 , at 564; UdOVITCH, supra note 59 , at $100,109$.

77. KASHAF, supra note 68, at 564; see also UdDovitch, supra note 59, at 99.

\section{PUBLISHED IN COOPERATION WITH}




\section{THE INTERNATIONAL LAWYER A QUARTERLY PUBLICATION OF THE ABA/SECTION OF INTERNATIONAL LAW}

IFLAS \& CHAPTER 11

sonal, non-partnership obligations of a partner like marriage and divorce obligations, and purely personal guarantees for third parties. ${ }^{78}$

The Mudaraba partnership, in which one (and now, potentially many) partner(s) provide only money and the other(s) provide material and "sweat equity," is without question the most important Islamic vehicle for modern Shari'a-compliant finance. As noted above, it both similar to and presumed to be the origin of the commenda contract that was the cornerstone of long distance trade as Europe emerged from the Dark Ages. ${ }^{79}$ While originally the mudaraba (also called "qirad"), like the commenda, was designed to finance caravans and maritime trade, ${ }^{80}$ there is no such actual restriction in the Shari'a. As a result, the mudaraba partnership form has become nearly the essential building block of modern Islamic financial investment vehicles. This is because the structure is designed to limit the liability of the "investor" to the amount invested.

In a classic mudaraba, a mudarib, or manager, takes money from the rabb al-mal, the investor, under a contract that provides for a sharing of the profits between them from the work performed exclusively by the mudarib (and his employees, etc.). The sharing percentage is set for in the contract. ${ }^{81}$

What distinguishes the mudaraba from a Western limited partnership is that the investor technically retains ownership of the capital he has contributed. ${ }^{82}$ This creates a unique construct under Shari'a because asset possession is controlled by someone who is not a buyer (title would pass), a lessee (there is no time period, only a purpose), or an agent (since the mudarib does not bind his principal, the rabb al-mal, for any deficiency but only binds his contributed assets). Nevertheless, because all actual assets of the partnership come from the rabb al-mal, in a mudaraba setting, the liability for loss falls entirely on the investor(s). But if the manager exceeds his authority, he may be personally liable. The general rule is that a manager in the mudaraba setting may buy on credit up to the agreed capital for the venture. He has to stop when accounts payable are equal to the capital employed. If he makes further purchases on credit, he needs special permission. Otherwise, he may be personally liable. ${ }^{83}$

All partnerships under Islamic law terminate at the will of any partner, death of a partner, insanity of a partner, or the destruction of the capital of the partnership. ${ }^{84}$ Additionally, a mufawada partnership terminates if there becomes an inequality in interest among the partners in the partnership, presumably through one making a payment of debts greater than another or the receipt of property eligible to be part of the partnership capital via gift or inheritance that creates an imbalance in the partnership capital. 85

As noted above, when distraint on a debtor takes place, he is treated as one who is a minor, insane, or incapacitated. He is prohibited from managing and disposing any of his assets, including assets that he has in a partnership. ${ }^{86}$ Thus, the distraint may well likely

\footnotetext{
78. Udovitch, supra note 59 , at 169.

79. See Harris, supra note 58, at 14-15.

80. Id. at 16-18.

81. AL-RAWD, supra note 61, at 320; KASHAF, supra note 68 , at 542-44.

82. Udovitch, supra note 59, at 170.

83. AL-RAWD, supra note 61 , at 321 ; KASHAF, supra note 68 , at 556-57.

84. Udovitch, supra note 59, at 117-18.

85. Id. at 118 .

86. IBN QUDAMAH, supra note 36 , at 537.
}

\section{PUBLISHED IN COOPERATION WITH SMU DEDMAN SCHOOL OF LAW}




\title{
THE INTERNATIONAL LAWYER A QUARTERLY PUBLICATION OF THE ABA/SECTION OF INTERNATIONAL LAW
}

\author{
988 THE INTERNATIONAL LAWYER
}

have the effect of terminating or dissolving the partnership. In sum, the insolvency of one partner could jeopardize the entire partnership venture.

As a result, all of the provisions that we will discuss below that apply to individual bankruptcies also apply to bankruptcies involving partnerships. In other words, the personal assets of the partners are fair game to the creditors to satisfy their debts. However, the Shari'a does have its own version of the famous, or infamous, common law Jingle Rule of partnership liability. ${ }^{87}$ While, as discussed below, there are no preferences for a partnership's business creditors to take precedence over personal creditors of a bankrupt partner, there is a requirement, somewhat similar to the common law equitable principle of marshaling of assets, that the partnership's assets be exhausted before a partnership creditor can assert a deficiency claim against the individual partners. ${ }^{88}$

\section{The Proceeding}

A bankruptcy proceeding is commenced by the creditors. ${ }^{89}$ One or more creditors will request from a judge, with jurisdiction over the location of the debtor, to issue an order to encumber or distrain the debtor. ${ }^{90}$

The burden is on the creditors to show proof of the debt and that the debt had become due. If the judge finds that he has enough assets to pay off his debts, the judge will order payment without distraining ${ }^{91}$ debtor. The judge could also decide that it is necessary to

87. The Jingle Rule gives partnership creditors priority over partnership assets as against creditors of the partners, and vice versa. It was formally codified in the Uniform Partnership Act, 1914, adopted in New York in 1919. It is still the law of New York. New York Partnership Law $\$ 71$ provides, in pertinent part:

(h) When partnership property and the individual properties of the partners are in the possession of a court for distribution, partnership creditors shall have priority on partnership property and separate creditors on individual property, saving the rights of lien or secured creditors as heretofore.

(i) Where a partner has become bankrupt or his estate is insolvent the claims against his separate property shall rank in the following order:

I. Those owing to separate creditors,

II. Those owing to partnership creditors,

III. Those owing to partners by way of contribution.

N.Y. P’ship Law $\$ 71$ (McKinney 2010).

88. Islamic law is similar to the approach adopted in the U.S. Bankruptcy Code. While in general, the Bankruptcy Code expressly treats all unsecured creditors the same according to the "absolute priority rule" of 11 U.S.C. $\$ 1129$ (b), 11 U.S.C. $\$ 723$ (a) provides:

(a) If there is a deficiency of property of the estate to pay in full all claims which are allowed in a case under this chapter concerning a partnership and with respect to which a general partner of the partnership is personally liable, the trustee shall have a claim against such general partner to the extent that under applicable nonbankruptcy law such general partner is personally liable for such deficiency.

11 U.S.C. $\$ 723$ (a) (2006) (emphasis added).

89. IbN Qudamah, supra note 36, at 570. Since there is no divine compulsion to pay one's debts under Western law, the Bankruptcy Code allows debtors to commence cases voluntarily, almost without limit. See 11 U.S.C. $\$ 301$. Three creditors with non-contingent and undisputed unsecured claims adding up to the statutory amount (now $\$ 13,475$ ) can commence an involuntary case. $\$ 303(\mathrm{~b})(1)$. If there are fewer than twelve such holders, only then can a single such creditor with a claim of that amount commence an involuntary case. $\$ 303(\mathrm{~b})(2)$.

90. IBN QUDAMAH, supra note 36 , at 570 .

91. The equivalent under the Bankruptcy Code is the "order for relief" issued by a bankruptcy judge in an involuntary bankruptcy case. 11 U.S.C. $₫ 303(\mathrm{~h})$.

\section{PUBLISHED IN COOPERATION WITH SMU DEDMAN SCHOOL OF LAW}




\section{THE INTERNATIONAL LAWYER A QUARTERLY PUBLICATION OF THE ABA/SECTION OF INTERNATIONAL LAW}

IFLAS \& CHAPTER 11

989

distrain the debtor while reviewing whether the debtor is solvent or insolvent. ${ }^{22}$ This has the effect of freezing the debtor's assets until further order by the court, which appear to be similar to an order of distraint in the common law (the "Distraint Order"). ${ }^{93}$ The issuance of the Distraint Order acts as an immediate preliminary injunction prohibiting the debtor from managing, disposing, or encumbering his or her assets.

Four legal consequences arise from the Distraint Order: (1) the creditor's rights attach to the debtor's property; (2) the debtor is prohibited from disposing of or managing his property; (3) the creditor that finds his specific actual property is more entitled than the rest of the creditors for its return; and (4) the debtor's property is liquidated to satisfy the creditors' debts. ${ }^{94}$

The legal authority for the Distraint Order is that the creditor's rights are attached to his property. ${ }^{95}$ A distrained person is treated like a minor, insane, or incapacitated person. ${ }^{96}$ The court will appoint a trustworthy person (rajul thiqab) [hereinafter Receiver] to manage the assets and business affairs of the bankruptcy in order to wind down the affairs of the debtor, gather and value the assets, and then liquidate the assets for distribution of the proceeds to the creditors. ${ }^{97}$ This is similar to virtually all of the Western civil and common law systems. ${ }^{98}$ It is also similar to the Bankruptcy Code procedure in Chapter 7, Liquidation, in which a trustee-in-bankruptcy is required to take possession of the debtor's assets. ${ }^{99}$ By contrast, it is the exact opposite of the process under Chapter $11 .{ }^{100}$ Under Chapter 11, the debtor is allowed to stay in control of his assets as the debtor-inpossession, although he is now imbued with all the legal rights of a trustee-in-bankruptcy. ${ }^{101}$ This is possible under the common law system because of the creation of a new "estate" in the form of a trust that acquires ownership of all of the debtor's pre-bankruptcy assets. ${ }^{102}$

The debtor's debts that are not due at the time of the Distraint Order will not be accelerated. ${ }^{103}$ The Hanbali position provides that only debts that are past due are included in

92. IBN QUDAMAH, supra note 36, at 537-38, 569-70.

93. A Distraint Order is the opposite of the automatic stay created by 11 U.S.C. $\$ 362$, and the similar suspension des poursuites and equivalents under other national laws that block. $\$ 362$. The concept of the distraint was first seen in Roman law. "A lex julia, attributed to Caesar by some, and to Augustus by others, removed the creditor's power one step further from the debtor as an individual and towards his property. The new legal system was called cessio bonorum .... The main objective of the execution, i.e. distraint, was no longer the debtor as a person and his body, but his property." Karl Gratzer, Insolvent, Thus a Swindler? The Insolvency Law And Imprisonment for Debt in Sweden, XIV InT'L Econ. History Cong., 45th Cong. 3-4 (2006).

94. IBN QUDAMAH, supra note 36, at 537.

95. Id. at 537; Kamali, supra note 8, at 47 (2008).

96. IBN QUDAMAH, supra note 36 , at 571 .

97. Id. at 577; BASYUNI, supra note 64 , at 242-43.

98. Mahmoud A. El-Gamal, Islamic Finance: Law, Economics, and Practice 15 (2007).

99. 11 U.S.C. $\$ 701(2010)$.

100. Id. $\$ 1104$.

101. Id.

102. Id. $\$ 541$. It is important to remember that Islamic law, exactly like traditional Western civil law, did not develop the concept of the trust (except for the charitable waqf). So, there is no artificial entity that can own the debtor's assets like the bankrupt estate under section 541 of the U.S. Code. Therefore, the function of the Distraint is in the form of injunctive relief for the creditors.

103. This is also the opposite of the bankruptcy statutes under U.S.C. All contingent debts, obligations, and causes of action are converted into claims, under section 101(5), and may be estimated under section 502(c).

\section{PUBLISHED IN COOPERATION WITH SMU DEDMAN SCHOOL OF LAW}




\section{THE INTERNATIONAL LAWYER A QUARTERLY PUBLICATION OF THE ABA/SECTION OF INTERNATIONAL LAW}

the proceeding. ${ }^{104}$ Debts that are not due are not accelerated. ${ }^{105}$ The argument by the Hanbali School is that the debtor is entitled to the additional time to satisfy the debt when it is due per contract. ${ }^{106}$ It is not due at this point, therefore, it should not be included in the bankruptcy proceeding. ${ }^{107}$

The liquidation takes place in an auction-like setting in an attempt to realize the highest price. ${ }^{108}$ The judge appoints a trustworthy man (rajul thiqab), who appears to be similar to a receiver and who would be responsible for fulfilling open contracts, canceling open contracts, and generally operating a business of the debtor, so long as the creditors agree. ${ }^{109}$ Of course, the receiver's actions are subject to the creditor and the judge. ${ }^{110}$ As such, the Shari'a receiver is very similar in powers and duties to his homologues in all Western systems, except Chapter 11, such as the administrators under British insolvency law. ${ }^{111}$

\section{The Creditors}

The debtor's estate includes all assets and any third-party claims due to the debtor, including damages from a negligence claim. ${ }^{112}$ All creditors, subject to class priorities, are treated equally. ${ }^{113}$ A creditor is defined as anyone who is entitled to a matured claim or right from the debtor. ${ }^{114}$

\section{A. Settlements and Compromises}

The creditors and debtor have the option to settle the debt. In that case, they would withdraw their request for the distraint of the debtor. ${ }^{115}$ Therefore, the debtor and the creditors have the opportunity to enter into negotiations to settle their respective claims. Of course, the settlement resolves the dispute and ends the litigation. Settlement is strongly encouraged under Islamic law as of matter of public policy. ${ }^{116}$

Islamic laws created two types of settlements.117 The first type is a settlement where the debtor denies the claim.118 This is a situation where a person claims a right against the debtor, but does not have a legally cognizable proof of the claim or right. ${ }^{119}$ The

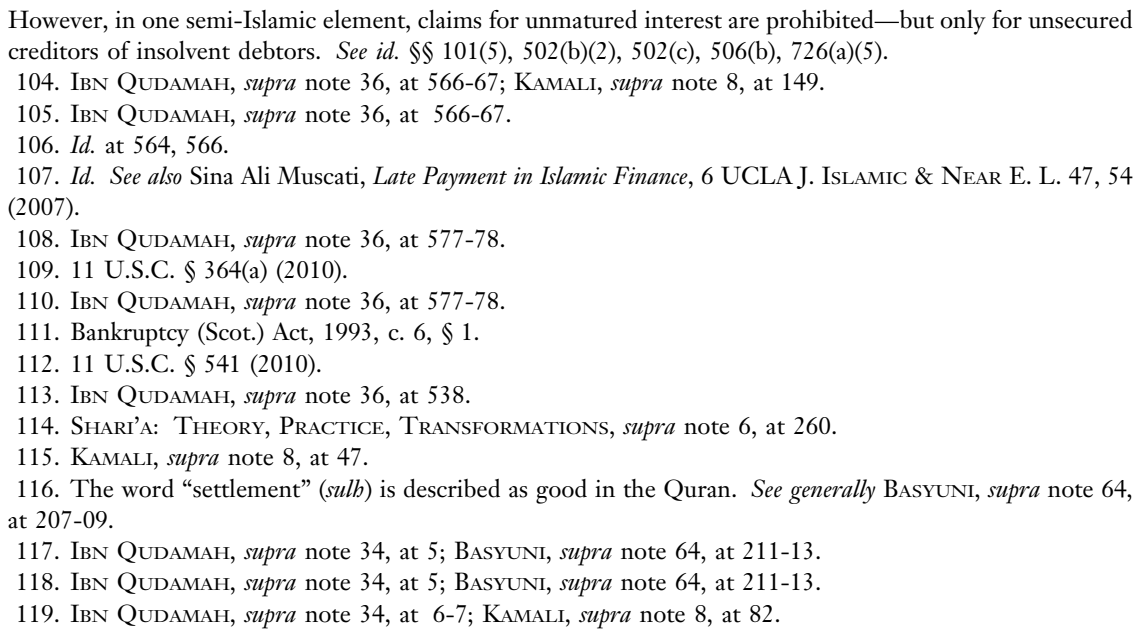

\section{PUBLISHED IN COOPERATION WITH SMU DEDMAN SCHOOL OF LAW}




\section{THE INTERNATIONAL LAWYER A QUARTERLY PUBLICATION OF THE ABA/SECTION OF INTERNATIONAL LAW}

IFLAS \& CHAPTER 11

991

settlement is based on compromise to avoid litigation. ${ }^{120}$ Some Muslim schools rejected this type of settlement. ${ }^{121}$ Some accepted it, but conditioned it upon the requirement that the defendant truly believe he does not owe the claim. ${ }^{122}$ If he believes he owes a claim, the money he saved is unlawful and considered an unlawful taking from a person fraudulently and falsely. ${ }^{123}$ The schools that rejected this type of a settlement said it is not legal because it is a compromise or an exchange of a right based on an unproven claim. ${ }^{124}$ Thus, it is not valid. Again, this highlights the directive to fulfill your obligations in your contract. 125

The second type is a settlement with the debtor based on what common lawyers call an admission against interest. ${ }^{126}$ A creditor claims a right and the debtor admits that he owes the creditor the claim. ${ }^{127}$ The creditor, as a compromise, accepts less money to settle the claim immediately. ${ }^{128}$ Many schools of law argued that such settlements are unjust and constitute an unlawful taking of a person's rightful claim, especially in light of the debtor's acknowledgment that he owes the debt. ${ }^{129}$ This is more an issue of form over substance. The jurists took a position that if the creditor compromised his right voluntarily (i.e., gave the reduction as a gift) the settlement was valid. ${ }^{130}$ Thus, they argue that it should not be called a settlement but rather a gift. ${ }^{131}$

\section{B. Classes and Priorities of Creditors}

Under the Islamic law of bankruptcy, the creditors are primarily classified in order of priority as follows:

\section{The Receiver}

Unless the receiver agrees to perform his services for free, the first priority to be paid from the liquidation of the debtor's assets remaining after the recoveries, referred to below by reclamation creditors, are the fees, expenses, and compensation of the receiver to manage the bankruptcy proceeding. ${ }^{132}$ These customarily include, but are not limited to,

120. Ibn QUdamah, supra note 34, at 7; Black's LaW Dictionary 124 (8th ed. 2004).

121. Ibn Qudamah, 3 Munaffaq al-Din Abu Muhammad Abd Allah Ibn Ahmad Ibn Muhammad, AL-MUGHNI FI FIQH IMAM AL SUNNAH AHMAD IBN HANBAL AL SHAYBANI 312 (abdallah ibn abd al muhsen al turki and abdel fatah muhammed al-hilu eds., 1988); IBN QUDAMAH, supra note 34, at 6; BASYUNI supra note 64 , at 312 .

122. IbN QUdAMAH, supra note 34, at 6. BASYUni, supra note 64, at 211-13.

123. IBN QUDAMAH, supra note 34 , at 7; KAMALI, supra note 8 , at 82.

124. IbN QudamaH, supra note 34, at 7; Kamali, supra note 8, at 82.

125. M. Cherif Bassiouni \& Gamal M. Badr, The Shari'ab: Sources, Interpretation, and Rule-Making, 1 UCLA J. Islamic \& NeAR E. L. 135, 149 (2002).

126. IBN QUDAMAH, supra note 34, at 5; BASYUNI, supra note 64, at 213-15.

127. IBN QUdAMAH, supra note 34, at 5; BASYUni, supra note 64, at 213-15.

128. Symposium, Islamic Finance: Resilience in a Time of Financial Crisis?, 2 Berkeley J. Middle E. \& IsLAMIC L. 159, 168 (2009).

129. Ibn Quduamah, supra note 34, at 5-7. Basyuni, supra note 64, at 212.

130. BASYUNI, supra note 64, at 212; see also KAMALI, supra note 8 , at 47 .

131. BASYUNI, supra note 64 , at 212; see also KAMALI, supra note 8, at 149.

132. IBN QUDAMAH, supra note 36, at 577 (explaining that the trustworthy person selected by the consent of the parties or order of the court either perform service for a fee, receive payment from liquidation or received payment from the government treasury (abyt al mal)); see also KAMALI, supra note 8, at 149.

\section{PUBLISHED IN COOPERATION WITH}




\title{
THE INTERNATIONAL LAWYER A QUARTERLY PUBLICATION OF THE ABA/SECTION OF INTERNATIONAL LAW
}

\author{
992 THE INTERNATIONAL LAWYER
}

transportation expenses, notices to the public, and reasonable expenses incurred by the receiver in operating the business, if necessary, as well as any necessary or reasonable expenses incurred by the receiver in enforcing or complying with contracts entered into by the debtor and/or those entered into by the receiver to operate the business, subject to the approval of the creditor(s) and the court. ${ }^{133}$

\section{Reclamation Creditors}

The second priority is for a creditor who is able to discover that his property is in the possession of the debtor. That creditor is entitled to demand return of his property as satisfaction of the debt or has the option to share with the creditors. ${ }^{134}$ As noted above, this is based on a Prophetic Sunna where it is believed the Prophet had said that if you find your property with the debtor, you are more entitled to take it back. ${ }^{135}$ The Muslim jurists developed a very complex and nuanced set of elements to be satisfied before a creditor/seller could take back his property from the debtor. ${ }^{136}$ The seller is entitled to return or take back his property if he satisfies five elements: 137

i. The debtor must be alive at the time a creditor seeks the return of his property. If debtor dies before the creditor secured the return of his property, the creditor loses his right to seek the return of his property. ${ }^{138}$ As such, all creditors then join together to share proportionate to their respective debts after liquidation of the debtor's property. ${ }^{139}$

ii. The property must also remain in the same state, undestroyed or undamaged, that it was when creditor sold it to the debtor. Therefore, where the creditor discovers his undamaged property in the possession and control of the debtor, he will be offered the option to take back his property as satisfaction for the debt or choose to share with the other creditors in proportion to his debt from the liquidation. ${ }^{140}$

iii. The creditor's property must continue to be in the possession and control of the debtor. If the property in question was delivered to the buyer/debtor and the debtor sold it, gifted it, pledged it, ${ }^{141}$ or no longer has the item in his possession, the creditor joins the other creditors in proportion to his debt from the liquidation. ${ }^{142}$

133. 11 U.S.C. $\$ \$ 327-30,326,503$ (b) (2010) (similarly gives these types of expenses of both a Trustee-inBankruptcy and the Debtor-in-Possession priority over unsecured creditors, plus adds for Trustees a percentage of all assets distributed to both secured and unsecured creditors).

134. See generally IBN Qudama, supra note 36, at 538. The much weaker equivalent under U.S.C. is the reclamation right of a vendor who delivered goods to a debtor within forty-five days before the commencement of the bankruptcy, under section 546(c). See 11 U.S.C. $\$ 546$ (2006).

135. Abu Abd Allah Muh?ammad ibn Ismail al-Bukhari, Sahih al-Bukhari, Jam'tyat al-Maknaz AL-Islämi (2000), Tradition Number 2166, vol. 3, book 41, no. 587 (according to the relevant Hadith, the Prophet Mohamed said: "If a person finds his specific property in the possession of a person who has become bankrupt, he/she is more entitled to it [than other creditors].").

136. See IbN Qudamah, supra note 36, at 543-90.

137. Id. at $543-90$.

138. $I d$. at 589 .

139. Id

140. Id. at 543-49.

141. See infra Section 4 (analyzing secured creditors).

142. IBN QUDAMAH, supra note 36, at 544, 562-64. If the pledged property is in excess of the secured debt, the pledge property is sold with the excess returned to the debtor. Id. at 562 . 


\section{THE INTERNATIONAL LAWYER A QUARTERLY PUBLICATION OF THE ABA/SECTION OF INTERNATIONAL LAW}

IFLAS \& CHAPTER 11

iv. If the debtor had paid the creditor any installment or down payment, the creditor is not entitled to take back his property. The other schools, however, provide the creditor with the option to either pay back to the Receiver the amount he received and take back his property as a satisfaction of the debt or share proportionately to his debts with the rest of the creditors. ${ }^{143}$

v. The Muslim jurist created laws to govern if the property that was in the possession of the debtor increased or changed or was converted somehow. ${ }^{144}$ If the property had increased or been transformed in a way that is directly linked to the actual property such as growth or aging, return is not available. ${ }^{145}$ If the property's increase or transformation is not directly linked to the actual property such as birth, harvest, and income, return is available as the increase if the entitlement of the debtor. ${ }^{146}$ For example, a debtor bought land from a creditor. He did not pay for the land. The debtor cultivated the land or built a home on the land before he became a muflis. The creditor then has three options:

(a) The creditor and the bankrupt person can agree to remove the improvement and return the land to the seller. The debtor is responsible for the damage to the land from removal of the improvement. ${ }^{147}$

(b) If the debtor and the creditor agree not to remove the improvement, the creditor simply gets to keep it along with the returned land. As far as planted crops are concerned, the creditor would take the land back with the planted crops, keep it until the harvest, and then pay the bankrupt person for the value of the harvest net of any reasonable costs incurred by the creditor in completing the cultivation, harvest, and sale of the crops.

(c) If the parties cannot agree, the parties will set up a forced option formula like a buysell agreement. The creditor gives the debtor the option to accept or reject his offer, to leave the planted crops on his property, or to allow the creditor to harvest the crops, sell the harvest, and give the proceeds to the debtor, net of any reasonable costs incurred by the creditor in completing the cultivation and harvest and sale of the crops. The debtor also can provide the creditor with an option to accept or reject the debtor's offer to keep the improvement on the land until the harvest and then sell harvest. ${ }^{148}$

The three preceding options apply when there is a clear differentiation between the original asset and the debtor's addition (e.g., comparing (1) land to crops or (2) land to a building built on it). But, when the debtor's addition is not so easy to distinguish from the original asset, different rules apply. ${ }^{149}$ If the inability to identify the seller's specific goods is (a) due to its having become part of a homogeneous larger quantity (most commonly because the debtor/buyer has bought a fungible commodity - such as oils or grains-from the seller and commingled it with that of others or the debtor's own) and (b) the creditor's goods and the others with which it was commingled are all of the same quality, the creditor is not entitled to the return of the property because the specific item no longer ex-

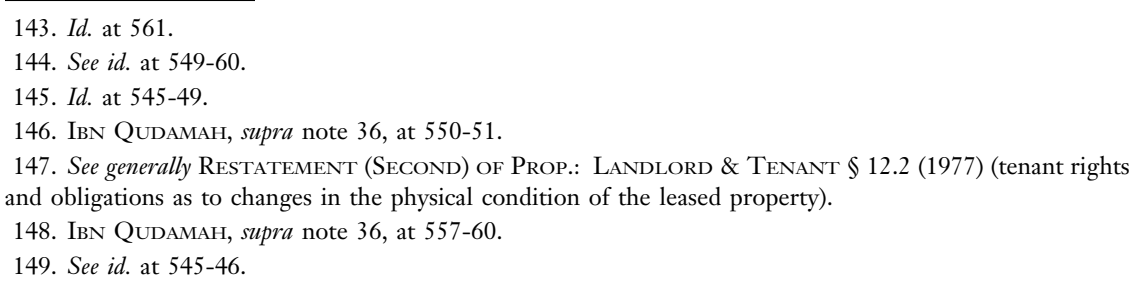




\title{
THE INTERNATIONAL LAWYER A QUARTERLY PUBLICATION OF THE ABA/SECTION OF INTERNATIONAL LAW
}

\author{
994 THE INTERNATIONAL LAWYER
}

ists. ${ }^{150}$ Several other schools allow the unpaid seller to unilaterally annul his contract and take back the weight of his oil or grain, even if it is not clearly the goods he sold. ${ }^{151}$ The minority school would argue that this outcome is not acceptable because the specific item no longer exists. ${ }^{152}$

But if the item is not of the same quality, then the seller has no right of return, and he shares with the creditors pari passu, meaning they each have equal right to payments. Similarly, if the seller's goods have been commingled with goods of a higher quality, there is no right of return, and seller shares with the creditors pari passu. ${ }^{153}$

Additionally, if the sold goods or items have been changed in a transformative way-for example, thread that is made to cloth, cloth is made into a garment, grain is milled into flour or wood made into a door-the right of recovery also does not exist; the seller becomes a creditor, and he shares with the rest of his class pari passu.154 On the other hand, if the conversion of the sold good is a change or improvement that is not transformative, such as cloth that was dyed, the Hanbalis say no right of return while several other schools allow the seller to recover the finished item because it is still the same category of good, but the seller must account for the cost of the work done by the debtor or the change in value that resulted from it. ${ }^{155}$

\section{Lessors}

Landlords have somewhat similar preferential rights. ${ }^{156}$ As noted above, the primary intangible asset recognized by Shari'a is the Ijara, a lease, whether of real estate or of personalty such as livestock. If a bankrupt lessee-debtor leases an animal or property, the lessor has the right to annul the contract and take back his property if the lease date did not commence. ${ }^{157}$ If the lease period expired, the lessor is a creditor for the unpaid rent. ${ }^{158}$ But if the lease period has commenced but has not expired, the lessor cannot annul it. In that case, actual property rights are owned by the lessee-debtor. The usufruct remains an asset of the bankrupt, while the lessor is a creditor for the unpaid rent. ${ }^{159}$

A similar priority for the usufruct is recognized when the landlord becomes bankrupt. In that circumstance, the Receiver remains subject to the terms and conditions of the

\footnotetext{
150. Id. at 545 .

151. Id. at $545-46$.

152. Id. at 545 .

153. Id.

154. Id. at $546-48$

155. Id. at 547 .

156. This position is adopted by the Maliki School of Law. See generally BASYunI, supra note 64, at 260-61; The Bankruptcy Code provisions dealing with real and personal leases are both varied and highly complex. Primarily included in $\$ 365$ along with those for "executory contracts," those contracts for which is performance is still due on both sides of the contract, there are a host of highly specialized provisions that deal with such things as changes in the tenant mix of a shopping center. 11 U.S.C. $\$ 365$ (b)(3)(A)-(D) (2006). The main focus involves whether the debtor's estate wants to continue the lease, abandon it or assign it for value to a third party. $\$ 365(\mathrm{a})$, (f). In addition, real property landlord's damage claims are limited to the future rent for a specified amount or period between one to three years of rent. 11 U.S.C. $\$ 502(b)(6)$ (2006). In addition, there are even more complex provisions dealing with such things as aircraft leases and ship charter parties. 11 U.S.C. $\$ 1110$ (2006)

157. IBN QUDAMAH, supra note 36 , at 541-42.

158. Id.

159. Id. at 541
}

\section{PUBLISHED IN COOPERATION WITH SMU DEDMAN SCHOOL OF LAW}




\section{THE INTERNATIONAL LAWYER A QUARTERLY PUBLICATION OF THE ABA/SECTION OF INTERNATIONAL LAW}

IFLAS \& CHAPTER 11

995

contract with the lessee. In other words, the lessee's contract will not be annulled or rescinded due to the landlord's bankruptcy because the use and benefit of the property is first in line, like a possessory pledge. 160 Of course, the income from the lease will revert to the Receiver and the Court.

\section{Secured Creditor}

Creditors with a secured interest get first priority against the collateral. ${ }^{161}$ As discussed above, classical Islamic law did not recognize most forms of intangible assets and rights other than the ownership right of a lessor. ${ }^{162}$ By virtue of this recognition of the ability to sever ownership rights from possessory rights, classical Islamic law also developed the ability of the owner of real property to enter into a written contract that created a residual right of ownership until the debt is repaid. ${ }^{163}$ This transaction, called a Murabaha, is a deferred sale or cost-plus transaction. 164 To illustrate: A wants to purchase a home but needs financing. B has the financing. A and B enter into a cost-plus agreement in which $\mathrm{B}$ buys the house then resells it to A in installments, which would include a reasonable profit. A has use and possession of the house until full payment is made to B, at which time B transfers ownership to A.

Besides a murabaha (and an ijara), the only other vehicle for creating a security interest under classical Islamic law was an actual possessory pledge (rabn). ${ }^{65}$ A creditor with pledged collateral to secure a debt has the right to seek repayment from the collateral. Of course, given the imperative to repay one's debts in full, if the sold or pledged item is not sufficient to pay the creditor's debt, the creditor will join the rest of the creditors for the balance remaining-in proportion to other creditors. ${ }^{166}$

\section{Personal Exemptions}

Classical Islamic law protects the debtor's reasonable (prevailing custom) living expenses and family's support from all creditors and the Receiver but not those assets that are subject to the claims of a secured creditor. They must be paid before anyone else. ${ }^{167}$

160. Id. at 571

161. Id. at 562,578 .

162. Sundahl, supra note 60. See also Silvia Beltrametti, The Legality of Intellectual Property Rights Under Islamic Law, Digital Islam, http://www.digitalislam.eu/article.do?articleId=2729 (last visited Oct. 16, 2010).

163. Abdul Awwal Sarker, Islamic Business Contract, Agency Problem and the Theory of the Islamic Firm, 1 INT. J. OF Islamic FIn. SERv's 17, available at http://eco.isu.ac.ir/edu/dlc/2rd/02/instructor/art2.pdf.

164. Press release, Bank of London And The Middle East Acts as One of The Lead Arrangers For Murababa Financing Deal in Turkey, Sept. 5, 2007, available at http://www.blme.com/pdfs/news/BLME\%20Murabaha\% 20deal\%20TFKB.pdf.

165. Definition of Major Islamic Finance Instruments, Islamic Finance Training, http://www.islamicfinance training.com/glossary.php (last visited Oct. 16, 2010).

166. IBN QUDAMAH, supra note 36, at 562; see Sundahl, supra note 60.

167. Ibn Qudamah, supra note 36, 574-575. This was also similar to the Jewish Torah. See generally Exodus 22:25-26 (Torah) ("If you take your neighbor's garment as security, until sunset you shall return it to him, for it is his only covering; it is his garment for his skin. With what shall he lie? And it shall be [that] if he cries out to Me, I will hear because I am gracious"). 11 U.S.C. $\$ 522(\mathrm{~b})(3)(\mathrm{A})$ (2006) (The Bankruptcy Code contains an intricate set of personal exemptions $(\$ 522)$ that are also subject to separate State law exemptions, in particular with respect to personal residences).

\section{PUBLISHED IN COOPERATION WITH SMU DEDMAN SCHOOL OF LAW}




\title{
THE INTERNATIONAL LAWYER A QUARTERLY PUBLICATION OF THE ABA/SECTION OF INTERNATIONAL LAW
}

\author{
996 THE INTERNATIONAL LAWYER
}

This includes clothing, shelter, food for the wife, children, and parents. ${ }^{168}$ Interestingly, several schools of law held that the creditors and the court must leave sufficient capital for the debtor to be able to continue his business or trade. ${ }^{169}$ The tools of the debtor's trade are also exempt from the creditors. ${ }^{170}$ Additionally, if the debtor owns a home, the home is also exempt from liquidation, ${ }^{171}$ subject in all cases to the rights under an ijara or murabaha.

While the Hanbali school provides that a debtor, if able to work, must work to pay off his debts, other school of law take the position that if the debtor has an income, he cannot be forced to work to pay off his debts. However, if he does work his income primarily will be utilized to support his family, food, shelter, and clothing. ${ }^{172}$ Whatever, if anything, remains will go to the creditors. ${ }^{173}$

\section{Other Priorities}

Classical Islamic law also recognized specific preferences and priorities for certain unsecured creditors. For example, if the owner of a farm is in bankruptcy, the farm's workers get priority to receive compensation for their wages from the sale of the harvest. ${ }^{174}$ Similarly, also reflecting the concept of possessory pledges, if the muflis delivered an item to an artisan to fix or contracted for an identifiable item to be made, the artisan receives priority for his fee, and he can hold the item until he is paid. ${ }^{175}$ The creditors have the option of paying him his fee and taking the item to be included in the debtor's estate. ${ }^{176}$ Otherwise, the artisan-creditor has the right to sell the finished goods and has first priority on the proceeds. ${ }^{177}$ The same is true for a carrier of goods, who has similar priority rights with respect to goods in his custody, but this is only so long as he has not released the goods to the debtor or a third party. ${ }^{178}$

168. IBN QUDAMAH, supra note 36 , at 574-76.

169. BASYUNI, supra note 64 , at 241.

170. Deuteronomy 24:6 (Torah) ("One shall not take the lower or the upper millstone as security [for a loan], because he is taking a life as security.”). See also 11 U.S.C.A. $\$ 522(\mathrm{f})(1)(\mathrm{B})(\mathrm{ii})$ (West 2004).

171. IBN QUDAMAH, supra note 36, at 576-77.

172. Id. at 580-82. See also 11 U.S.C.A. $\$ \$ 541,1115$ (West 2004) (demonstrating that this is an area where there is dramatic difference between a Chapter 7 liquidation under the Bankruptcy Code and Chapter 11, as in Chapter 7, all of a debtor's income from the moment after the commencement of the case is free from all of the claims of the pre-existing (or "prepetition") creditors, but under Chapter 11, since the business enterprise is intended to be rehabilitated, all of its "postpetition" income remains part of the bankruptcy estate usable to reorganize the debtor).

173. IBN QUDAMAH, supra note 36, at 580-82; see also 11 U.S.C.A. $\$ 726$ (a)(6) (West 2004) (indicating that the final distribution under Chapter 7 is identical).

174. BASYUNI, supra note 64 , at 262; see also 11 U.S.C.A. $\$ \$ 503(\mathrm{~b}), 507$ (a)(4) (including a long list of priorities and limited amounts for prepetition wage claims).

175. IBN QUdAMAH, supra note 36, at 548-49; see also Black's LaW DictionaRy 429 (3d pocket ed. 2006) (demonstrating a similarity to statutory and common law workmen's and mechanics' liens under western systems).

176. IBN QUDAMAH, supra note 36, at 548-49.

177. Id.

178. BASYUNI, supra note 64 , at 88-90, 262-63.

\section{PUBLISHED IN COOPERATION WITH SMU DEDMAN SCHOOL OF LAW}




\section{THE INTERNATIONAL LAWYER A QUARTERLY PUBLICATION OF THE ABA/SECTION OF INTERNATIONAL LAW}

IFLAS \& CHAPTER 11

997

\section{All other creditors}

All other creditors are considered regular creditors that do not have any priority. They all share equally proportionate to their debts. ${ }^{179}$ Given that there is no final discharge and the debtor is responsible indefinitely to pay off his debts, there is no "bar date" or other barrier against creditors sharing in the debtor's assets that may be remain, even if they had not known the debtor was previously distrained.

\section{Creditor Enforcement Mechanisms}

To enforce their valid rights, the creditors of a debtor, muflis or not, have three primary tools: 1) request the imprisonment of the muflis until he pays his debt, ${ }^{180} 2$ ) follow the debtor around in his business and in his daily routine to find any assets that can be liquidated, ${ }^{181}$ and 3) prohibit his travel. ${ }^{182}$

\section{Imprisonment}

Imprisoning, or enslaving debtors was a factor of debtor-creditor law as far back as we have records. The Code of Hammurabi (c. 1795-1750 B.C.) provided for both, and for the debtor's entire family (Laws 115 and 117), ${ }^{183}$ but also provided for a finite term not to exceed four years. ${ }^{184}$ And both Australia and the American colony of Georgia were used by the British as penal colonies. ${ }^{185}$ It is therefore not surprising that classical Islamic law included imprisonment for non-paying debtors. Given the lack of a possibility of a discharge of one's debts, the Shari'a did not incorporate a fixed term, like Babylonian ${ }^{186}$ or Jewish ${ }^{187}$ law. But Islamic law did follow and amplify an element that first appeared in the Code of Hammurabi ${ }^{188}$ and then later Roman law: ${ }^{189}$ the socially responsible, and arguably charitable, distinction between debtors who are victims of some form of force majeure and those who are reasonably at fault for their defaults. Classical Islamic law went further. Under the Shari'a, if the debtor can simply demonstrate or prove that he has no money or salable assets or he is not able to pay, he will not be imprisoned.190 This effectively, for all

\footnotetext{
179. IBN QUDAMAH, supra note 36, at 589.

180. Id. at $585-89$.

181. Id. at $589-90$

182. Id. at 591-92.

183. The Code of Hammurabi 115, 117.

184. Hammurabi 117. The Jewish Torah had a longer term before discharge, six years, but did not provide for inclusion of the family members. Deuteronomy 15:1-3, 12 .

185. Jihyeon Park, The History of Penal Colonies (July 2008), available at http://www.zum.de/whk$\mathrm{mla} / \mathrm{sp} / 0809 / \mathrm{pjh} / \mathrm{pjh} 1 . \mathrm{html}$.

186. Hammurabi 117.

187. Deuteronomy 15:1-2.

188. Hammurabi 48, 103.

189. Gratzer, supra note 93 ("The main objective of the execution, i.e. distraint, was no longer the debtor as a person and his body, but his property . . . In order to prevent . . . abuse, this exemption was restricted to those cases where the debtor was found not to have caused his insolvency. Only those who could show that they had become bankrupt due to external circumstances (such as fire, shipwreck, attacks from robbers, etc.) were exempt from disgraceful treatment. In those cases where the debtor himself was considered to have caused his insolvency, cessio bonorum still meant infamy and severe treatment.").

190. IBN QUDAMAH, supra note 36, at 585-90.
}

\section{PUBLISHED IN COOPERATION WITH SMU DEDMAN SCHOOL OF LAW}




\title{
THE INTERNATIONAL LAWYER A QUARTERLY PUBLICATION OF THE ABA/SECTION OF INTERNATIONAL LAW
}

\author{
998 THE INTERNATIONAL LAWYER
}

intents and purposes, eliminated debtor prisons. The jurists intimated that what is the benefit of imprisoning someone who does not have any money. ${ }^{191}$ This is exactly consistent with the Quranic command: "If a person is in difficulties, let there be respite until a time of ease." 192

A muflis may be imprisoned for a short period of time to determine the credibility and veracity of his claim of an inability to pay his debts. ${ }^{193}$ If the court determines that he does in fact have money or salable assets and just refuses to pay his debts, he can be imprisoned until he makes full payment of his debts. ${ }^{194}$ On the other hand, if it is unknown whether he has the ability to pay, he is jailed until the judge determines the truth of his insolvency. ${ }^{195}$ Ultimately, if it is found that he is insolvent, he will be released. ${ }^{196}$ Some madhaheb have taken exception with this argument, saying that incarcerating a person is a punishment for a wrong and that incarcerating a person is a serious, extraordinary measure that should not be utilized unless and until there is substantial proof that he has the ability to pay and willfully refuses to pay. ${ }^{197}$ The duration of the sentence is within the discretion of the judge. ${ }^{198}$

\section{Monitoring and Putting Pressure on the Muflis}

Reflecting the more benign approach of Shari'a to debtors, as required by Verse 2:280, public opprobrium and surveillance replaces much more draconian practices, such as those mandated in the early Roman Law of the Twelve Tables. ${ }^{199}$ Islamic creditors instead were allowed to follow a non-paying debtor around to see if they can catch him with any property. 200 They are also authorized to publically announce that the debtor owes him a debt and is not a trustworthy person. ${ }^{201}$

\section{Travel restrictions}

If requested by a creditor that the bankrupt debtor be restricted in his travel outside the town or city so that he is not able to dissipate or hide assets, the court will consider the surrounding circumstances to determine whether an order restricting the travel should be issued. The court would assess whether a pledge of assets as surety, or another mecha-

\footnotetext{
191. Id. at 585 .

192. Id. at $585-87$.

193. Id. at 585 .

194. Id. at $585-86$.

195. Id. at 585 .

196. Id. at $585-87$.

197. Id. at 588 .

198. These are the same criminal procedural safeguards in Islamic criminal law that prevent incarceration when there is suspicion or the proofs do not rise to the beyond a reasonable doubt standard.

199. See The Tivelve Tables: Table III.1-Debt, June 10, 2009, available at http://www.csun.edu/ hcfllo04/12 tables.html. "When a debt has been acknowledged or a judgment has been pronounced in court, 30 days must be the legitimate grace period. Thereafter, arrest of the debtor may be made by the laying on of hands. Bring him into court. If he does not satisfy the judgment (or no one in court offers himself as surety on his behalf) the creditor may take the debtor with him. He may bind him either in stocks or fetters, with a weight of no less than $15 \mathrm{lbs}$. (or more if he desires.)" Id.

200. IBN QUDAMAH, supra note 36, at 588; 18 U.S.C $\$ 152$ (2010).

201. IbN Qudamah, supra note 36, at 588-89.
}

\section{PUBLISHED IN COOPERATION WITH SMU DEDMAN SCHOOL OF LAW}




\section{THE INTERNATIONAL LAWYER A QUARTERLY PUBLICATION OF THE ABA/SECTION OF INTERNATIONAL LAW}

IFLAS \& CHAPTER 11

999

nism, is necessary to insure the debtor's return. ${ }^{202}$ In general, the debtor can request permission to travel based on reasonable grounds such as health, pilgrimage, family obligations, etc. ${ }^{203}$

Based on the other debt-related sanctions under the Shari'a, it is fair to conclude that if the court determines that the muflis does not have the ability to pay the debt(s) in question, the travel restriction ceases. ${ }^{204}$

\section{Conclusion}

As we discussed above, the classical Islamic law of bankruptcy was quite developed. The legislators in many participating countries of the Organization of the Islamic Conference will undoubtedly want to rely on this rich body of Islamic jurisprudence to inform and inspire the reevaluation of their current bankruptcy laws in light of the recent economic meltdown and the deficiencies in their existing national bankruptcy laws. Of course, the objective economic, social, and political circumstances of the twenty-first century are different than those prior to the fourteenth century. Nevertheless, there is abundant room for internal evolution and reform that is adaptable to the present conditions from within the rich Islamic jurisprudential heritage.

Above all, the treatment of a muflis under classical Islamic law is strongly analogous to the traditional civil and common law treatment of bankrupts prior to the enactment of Chapter 11 of the U.S. Bankruptcy Code in 1978. Prior to Chapter 11, bankruptcy laws had as their primary, if not sole, function a fair and equitable distribution of the debtor's assets among his or her creditors. The revolutionary change of Chapter 11 was to make the paramount purpose of the insolvency proceeding the rehabilitation of the business enterprise. As non-Islamic law used the mechanism of the discharge to avoid punishing debtors and letting them lead a debt-free life, the Shari'a kept the debt from increasing over time while imposing moral suasion to reach settlements and forgive unsustainable debts.

To develop a Shari'a-compliant version of Chapter 11, Muslim nations must first accept, as did the United Nations Commission on International Trade Law, that the economic continuation and revival of ongoing business enterprise is more important, as a public policy matter, than the maximum short term satisfaction of the business's debts. As we have shown above, strictly speaking the simple Chapter 11 solution of a debt discharge through a Plan of Reorganization is not permitted, because a Muslim is obligated to repay his or her debts. However, under the Islamic concept of settlement (sulb) a creditor could accept a compromise or reduction of the debt. The moral theory for such reduction is that creditor would make a donation or charitable forgiveness of the remaining balance. Developing a plan of reorganization has substantial authority in Islamic law with the Quranic directive to extend the time the debtor has to pay and to freely forgive. This concept needs to be developed further. The question is whether the reorganization plan that would include an across-the-board reduction of the creditors' debts involuntarily would pass the requirement to fulfill one's obligations. In other words, this concept could

202. Id. at 591 .

203. Id.

204. Id. at $591-92$. 


\title{
THE INTERNATIONAL LAWYER A QUARTERLY PUBLICATION OF THE ABA/SECTION OF INTERNATIONAL LAW
}

\author{
1000 THE INTERNATIONAL LAWYER
}

replicate many of the elements of a consensual Plan of Reorganization under 11 U.S.C. $\$ 1129$ (a); although not the "cramdown" Plans provided for in $\$ 1129$ (b).

There is no question that the orderly development of Islamic finance will require finding ways to amalgamate the classical Islamic law of bankruptcy with the needs of the modern Islamic finance industry. The unreasonable reliance on ever-expanding opportunities has disappeared along with the global credit markets. It is therefore inescapable that loss scenarios must be dealt with. That in turn means effective bankruptcy laws. We hope this article will help foster the effort. 